\title{
NALLD NEWS
}

NALLD Vice President and Program Chairman, Victor Aulestia, has arranged for a series of exciting NALLD presentations at the forthcoming ACTFL convention in Boston. All presentations will be given in Beacon $A$ at the times indicated:

November 22, 1980 The Future of Interactive Instruction via Videodisc 11:15 AM - 12:15 PM Microcomputers

12:30 PM - 1:30 PM New Aids to Language Learning-Thanks to the Interactive Videodisc

3:00 PM - 4:00 PM NALLD Business Meeting-International Conference on Foreign Language Education and Technology

November 23, 1980 Consulting the Media Experts-NALLD Symposium 10:00 AM - 12 Noon on the Language Laboratory

For more information, contact:

\author{
Victor Aulestia Director \\ Dept. of Instructional Media Resources \\ University of Maryland Baltimore County \\ Catonsville, MD 21228 \\ (301) 455-3208
}

Announcing the formation of a new foreign language association in Canada ASSOCIATION OF FRENCH SCHOOLS OF QUEBEC

The French Summer schools of Quebec have recently joined forces in a new-non-profit association with the aim of helping students and teachers interested in the following types of programs: Intensive language training, cultural exchange, total immersion, teaching of French as a second language, Quebec culture and civilization.

This recently founded organization currently includes eleven (11) universities and colleges throughout Quebec. It intends to act as a clearing house distributing information to any individual, group or institution interested in improving their knowledge of the French language or learning more about Quebec culture.

For additional information contact:

Association of French Schools
of Quebec
3333 Chemin Reine Marie
6th Floor
Montreal, Quebec H3C 317

National Council on Foreign Language and International Studies Formed

A group of eighteen leaders from business, labor, government, education, and the media has formed a new organization to focus public attention on the nation's declining competence in foreign languages and 
the urgent need for improved understanding of international affairs. The National Council on Foreign Language and International Studies, recently chartered in New York, held its first meeting last May.

Establishment of the Council was recommended last year by a presidential commission. Arthur Taylor, managing partner of Arthur Taylor Co. of New York, and formerly president of CBS, Inc. was elected chairman, while James A. Peskins, chairman of the International Council for Educational Development, was named vice chairman. Ernest L. Boyer, president of the Carnegie Foundation for the Advancement of Teaching and until recently U.S. Commissioner of Education, was elected secretary treasurer. Allen $\mathrm{H}$. Kassof, executive director of the International Research and Exchanges Board (IREX) has been asked to serve also as the new Council's executive director.

The Council will develop a national agenda for the improvement of U.S. performance in the overseas markets, and in the conduct of foreign affairs through the upgrading of language proficiency and international studies. The Council, assisted by a panel of senior advisers made up of professionals in the field, will make special efforts to involve the interest of the business community and the foundations, as well as the government, in improving international education and language studies. Initial financial support for the Council comes from a combination of corporate, foundation, and governmental sources. These include the Ford, Rockefeller, and Hewlett Foundations, the Exxon Educational Foundation, and the U.S. International Communications Agency. The Council sees its mission as complementing and encouraging the work of institutions already involved in international education and research. The National Council on Foreign Language and International Studies is located at 605 Third Avenue (17th Floor), New York, NY 10016. 